\title{
From Treaty Revision to Treaty Revision: The Legacy of Maastricht
}

\section{Desmond DINAN}

By one measure, albeit simplistic, the Maastricht Treaty was merely the second in a series of major changes to the founding treaties of the European Community (EC) that took place over a period of nearly twenty-five years, beginning with the Single European Act (SEA), negotiated in 1985, and ending with the Lisbon Treaty, implemented in 2009. Before the mid-1980s, treaty change in the EC was not unknown, but had limited scope and political significance. ${ }^{1}$ By contrast, the SEA and Maastricht Treaty altered the EC fundamentally, not least by realizing the long-standing goal of a single market and launching the European Union, which incorporated a variety of ambitious undertakings such as Economic and Monetary Union (EMU), the Common Foreign and Security Policy (CFSP), and cooperation on Justice and Home Affairs (JHA). The SEA and the Maastricht Treaty are directly linked in origin and importance; they stand out as closely-related developments, almost as a single "foundational treaty change". Subsequent treaty changes proved far less consequential but much more controversial.

Treaty change is a complicated and potentially contentious process, requiring intense intergovernmental negotiations and unanimity among national governments. ${ }^{2}$ Informal political agreements among national governments can have the same effect as formal treaty changes, but lack legal protection and can also be difficult to reach. The infamous Luxembourg Compromise of 1966, which thwarted the widespread use of qualified majority voting (QMV) as an instrument of legislative decision making, is a striking example of a political agreement that had the effect of a treaty change. ${ }^{3}$ As an alternative to what became the SEA, British Prime Minister Margaret Thatcher proposed simply that the voting provisions of the original treaty be fully honoured, thereby facilitating decision-making by means of QMV on a range of single market issues. ${ }^{4}$ The call by the European Council in June 1985 to proceed with formal treaty change, and the weightiness of the ensuing SEA and Maastricht Treaty, tipped the balance firmly in favour of such an approach to deepening European integration. ${ }^{5}$

1. F. LAURSEN, Introduction: On the Study of EU Treaties and Treaty Reforms, in: F. LAURSEN (ed.), Designing the European Union: From Paris to Lisbon, Palgrave Macmillan, Basingstoke, 2012, pp.1-16.

2. D. BEACH, C. MAZZUCELLI, Introduction, in: D. BEACH, C. MAZZUCELLI (eds), Leadership in the Big Bangs of European Integration, Basingstoke, Palgrave Macmillan, 2006, pp.1-21.

3. J.M PALAYRET, H. WALLACE, P. WINAND, Visions, Votes and Vetoes: The Empty Chair Crisis and the Luxembourg Compromise Forty Years On, Peter Lang, Brussels, 2006.

4. "Europe: The Future", paper presented by Prime Minister Margaret Thatcher to the Fontainebleau European Council, 25-26.06.1984, reproduced in: Journal of Common Market Studies, 23(1984), pp.73-81.

5. Milan European Council, Presidency Conclusions, Bulletin EC, 6(1985). 
What accounts for formal treaty change in the post-Maastricht period? Why has it been so pervasive and divisive? Why have the twenty-five years since the SEA been dominated by major treaty change, in marked contrast to the preceding twenty-five years? One explanation for the persistence of treaty change hinges on the need to complete unfinished business. Despite the enormous effort put into the Maastricht negotiations, inevitably some policy and institutional issues remained incomplete and would need to be revisited in due course. Similarly, the impact of the SEA and Maastricht would likely cause a degree of spill-over by raising institutional and policy issues, either anticipated or unexpected, that would have to be tackled in another intergovernmental conference (IGC), a prerequisite for treaty change. A review clause in the Maastricht Treaty, calling for an IGC within five years of the treaty's implementation, specifically mentioned unfinished business, notably in relation to the CFSP. Additionally or alternatively, a feeling that major treaty change, in the form of the SEA and Maastricht, had contributed decisively to the acceleration of European integration may have led EU leaders to look benignly at the prospect of further treaty reform, seeing it as a means of achieving "ever closer union".

Even without tackling spill-over or tidying up loose ends, the possibility of postMaastricht treaty reform would likely have arisen in any case because of two sets of circumstances that were already apparent in the early 1990s but became pressing thereafter: the challenge of democratic legitimacy and the unprecedented nature of Central and Eastern European enlargement. Yet these developments shaped the agen$\mathrm{da}$, negotiation, and outcome of the post-Maastricht IGCs in ways that severely limited the utility of treaty reform as a method of deepening European integration. Far from allaying public concern and strengthening the EU's legitimacy, treaty reform in the post-Maastricht period seemed to exacerbate the much-maligned "democratic deficit". At the same time, anxiety among national governments over the implications of enlargement for influence in decision-making institutions intensified rivalry between the big and small member states, which dominated the conduct of IGCs at the highest level - the heads of state and government - and ensured sub-optimal results.

This article explores the legacy of the Maastricht Treaty in terms of further treaty change, which can be divided into two distinct stages. First, in the ten-years following the Maastricht Treaty, national governments negotiated the Amsterdam and Nice treaties. The Amsterdam Treaty of 1997 contained a useful but unspectacular set of amendments, especially with regard to the functioning of cooperation in the area of JHA, but failed conspicuously to resolve urgent institutional problems. Even at the time, the Nice Treaty of 2000 seemed highly unsatisfactory, specifically because of the negotiators' inability to achieve their stated goal of far-reaching institutional reform. General dissatisfaction with Nice triggered the second stage of post-Maastricht reform, which began even before implementation of the Nice Treaty itself. Hoping to restore confidence in the efficacy of treaty reform and reanimate European integration, EU leaders took an explicitly constitutional turn in the Laeken Declaration of December 2001, which sparked the Constitutional Convention and led to the Constitutional Treaty of 2004. Yet the factors that had derailed effective treaty reform in 
the 1990s persisted into the next decade, souring the IGCs that preceded the Constitutional and Lisbon treaties and contributing to the negative referendum results.

Treaty change will continue in the EU, but large-scale reform along the lines of Maastricht, Amsterdam, or Lisbon is unlikely to be attempted again, notwithstanding the fallout from the eurozone crisis. To some extent the EU has returned to the past, tinkering with the founding treaties by making relatively narrow - though not insignificant - changes, especially in response to the eurozone crisis. As it happens, the eurozone crisis highlights the need for far-reaching treaty change that would strengthen the fundamentals of EMU, but such a development may be politically impracticable thanks to the legacy of major treaty reform in the post-Maastricht period. Ironically, major EMU-related treaty reform in the post-Lisbon era - were it ever to happen - would constitute unfinished Maastricht business.

\section{The SEA and Maastricht: Foundational Treaty Change}

The SEA and Maastricht anchor the series of treaty changes that took place between the mid-1980s and late 2000s. ${ }^{6}$ The impetus for the main components of the SEA and Maastricht - the single market program and monetary union, respectively - was economic: pervasive concern about Western Europe's relative weakness at a time of accelerating globalization. Whereas all national governments, as well as the governments of some non-member states, such as Sweden, supported greater market integration, encapsulated in the SEA, as a necessary response to global economic interdependence, the same was not the case with monetary union. While the Commission and some national governments saw EMU as a desirable and inevitable spill-over from the single market program, other governments, such as Britain's, disputed both its economic necessity and political wisdom. Geo-political changes may well have affected the timing and the political dynamics of the inter-governmental conference that resulted in the Maastricht Treaty, but EMU was well on track by the time that the Berlin Wall came down.

By contrast, geo-political changes account squarely for two other components of the SEA and the Maastricht Treaty: provisions for European Political Cooperation (EPC) and the Common Foreign and Security Policy, respectively. Ironically, the changes in question were radically different preceding the SEA and the Maastricht Treaty. In the case of the SEA, it was the intensification of Cold War hostility in the early 1980 s that impelled national governments to explore ways of strengthening the

6. On the SEA and Maastricht, see M.J. BAUN, An Imperfect Union: The Maastricht Treaty and the New Politics of European Integration, Westview Press, Boulder, 1992; D. DINAN, The Single European Act: Revitalizing European Integration, in: F. LAURSEN, Designing the European Union ..., op.cit; C. ENGEL, W. WESSELS, From Luxembourg to Maastricht: Institutional change in the European Community after the Single European Act, Europa Union Verlag, Bonn, 1992; C. MAZZUCELLI, The Treaty of Maastricht, in: F. LAURSEN, Designing the European Union ..., op.cit., pp.244-286. 
decade-old mechanism of EPC in order to boost Western Europe's standing vis-à-vis Washington and Moscow. In the case of Maastricht, it was the winding down of the Cold War, and then its sudden end, that impelled national governments to replace EPC with a more robust and overtly security-related CFSP in order to ensure a voice for the nascent EU in the emerging, post-Cold War strategic environment. Even so, different tendencies among national governments - neutralist, Atlanticist, and Europeanist - bedevilled negotiations on the EPC and CFSP components of both treaty changes.

The geo-political and the economic drivers and components of the SEA and Maastricht highlight another close link between the two treaty changes: the pillar structure of the post-SEA European Community and the post-Maastricht European Union. By bringing EPC formally under the umbrella of the EC, as happened in the SEA, national governments implicitly established a second, intergovernmental pillar alongside the original socio-economic pillar, with the single market at its core. The existence of the pillar structure became explicit in the Maastricht Treaty. Alongside the supranational pillar, which now included EMU, governments established separate intergovernmental pillars for the CFSP and for cooperation on JHA.

Institutionally, strengthening the legislative authority of the European Parliament (EP) and extending the scope of QMV to additional policy fields tie the SEA and the Maastricht Treaty together. The rationale for the former was democratic legitimization of the EC and later the EU; the rationale for the latter was to improve the efficiency of the legislative process. The SEA introduced the cooperation procedure, the first step on the road to giving the EP real legislative power; the Maastricht Treaty went far beyond that by introducing codecision between the EP and the Council of Ministers in legislative decision-making, though not yet in a way that put both institutions on an equal footing. Within the Council itself, the policy scope of QMV, extended in the SEA to most single-market measures, was further extended in the Maastricht Treaty.

Several officials and politicians from across the EC had participated in negotiations for both the SEA and the Maastricht Treaty. For many of them, Maastricht was an opportunity not only to go beyond the relatively limited confines of the SEA but also to correct some of the institutional shortcomings of the SEA itself. Moreover, the geo-political context in which the Maastricht negotiations took place, and the more ambitious scope of the new treaty, gave the occasion greater historical significance. For national leaders and the European Commission President, who participated in the final negotiating session in Maastricht in December 1991, the sense of historymaking was palpable, much more so than in the concluding session of the pre-SEA intergovernmental conference, in Luxembourg, in December 1985. Never mind that the negotiations themselves became mired in seemingly petty disputes over institutional arrangements and Britain's rejection of the draft treaty's social policy provisions. Basking after the Maastricht summit in the glow of media attention, most of the principal negotiators emphasized the momentous nature of the event, notably the decision to recast the doughty old EC as the shining new EU. 
The Maastricht Treaty was the second major treaty change within five years, and was closely-related to the first. For nearly three decades before the SEA, the Rome Treaty had been revised in only relatively minor ways. Nevertheless the nature of the EC had changed appreciably, notably as a result of intergovernmental agreements, ranging from the Luxembourg Compromise of 1966, to the decision to hold the first direct elections for the EP in 1979, to successive rounds of enlargement, which increased the number of member states from six to twelve. It would have been naive of the SEA and Maastricht negotiators to think that the new EU settlement would endure without change for the foreseeable future. Although none could have predicted the sequence of treaty changes during the next two decades, all must have appreciated that the EU would indeed evolve not only informally but also formally through further intergovernmental agreements. Two factors, in particular, suggested that additional change was highly likely. One was a provision in the Maastricht Treaty calling for another IGC within five years to revise, if necessary, the functioning of the CFSP. The other was future enlargement to include, first, those members of the European Free Trade Association (EFTA) drawn to the EC by the single market program and unconstrained, following the end of the Cold War, by concerns about neutrality; and, second, the newly-independent countries of Central and Eastern Europe. It was the seemingly inevitable accession of the second set of prospective member states that caused EU leaders, by the mid-1990s, to realize that the post-Maastricht constitutional settlement would not endure for long without major treaty changes.

Additionally, the SEA and the Maastricht Treaty had let the genie of public opinion out of the bottle. ${ }^{7}$ Hitherto, the EC was largely unimpeded by public opinion, which paid relatively little attention to what took place in "Brussels", at the European level of governance. The excitement of the single market program and the promise of a border-free Community attracted public attention, initially in the form of widespread support. Despite the obvious convenience of being able to use the same currency across national borders, however, public opinion was not as enthusiastic about EMU, which cut much closer to the core of national sovereignty and threatened to constrain national fiscal policies in unpopular ways. At the same time, resentment of the EC's post-SEA regulatory zeal, epitomized by the inherently unpopular Commission, stoked incipient Euroscepticism. Rejection of the Maastricht Treaty in the first Danish referendum brought matters to a head. ${ }^{8}$ Having ridden an unexpected wave of popular support at the height of the single market euphoria, the new EU was suddenly thrown on the defensive. Already sensitive to claims that the EC suffered from weak democratic legitimacy, EU leaders in the post-Maastricht period grasped the importance of strengthening - or being seen to try to strengthen - the EU's democratic credentials in order to boost the organization's legitimacy and halt the rise of

7. R. DALTON, R. EICHENBERG, Citizen Support for Policy Integration, in: W. SANDHOLTZ, A. STONE SWEET (eds), European Integration and Supranational Governance, Oxford University Press, Oxford, 1998, pp.250-282; M. GABEL, Public Support for European Integration: An Empirical Test of Five Theories, in: Journal of Politics, 60(1998), pp.333-354.

8. F. Laursen, S. Vanhoonacker (eds), The Ratification of the Maastricht Treaty: Issues, Debates, and Future Implications, Martinus Nijhoff Publishers, Dordrecht, 1994. 
Euroscepticism. Further treaty changes, or other intergovernmental and inter-institutional agreements, would give the EU an opportunity to do so.

\section{Grappling With Enlargement}

The new EU's architectural design seemed inherently unbalanced, or at least inelegant. The first, supranational pillar was vastly stronger than the two intergovernmental pillars. By including these pillars in the Maastricht Treaty, governments acknowledged the importance of cooperating more closely within the EU on foreign and security policy, and on asylum, immigration and internal security. Yet the relative weakness of the intergovernmental pillars reflected governments' unwillingness to extend supranational decision-making to the highly-sensitive areas of CFSP and JHA.

Developments on both fronts in the immediate post-Maastricht period highlighted the inadequacy of the existing institutional arrangements and policy instruments. In particular, the EU's inability to broker or impose a ceasefire in the Balkans, which had erupted in conflict just as the Maastricht Treaty was being concluded, demonstrated the need for a more muscular EU foreign policy. Though less dramatic, developments relating to asylum, immigration, and cross-border crime stoked public support and political pressure for more effective EU action in the area of JHA. The post-Maastricht IGC, due to take place within five years of the treaty's implementation, provided an ideal opportunity to revise not only CFSP - as originally planned - but also JHA procedures.

Arguably the most pressing EU policy issue in the post-Maastricht period, however, was not CFSP but a different aspect of external relations: enlargement. In 1995, Austria, Finland, and Sweden joined the EU. The so-called EFTA enlargement was relatively easy for the EU to manage. ${ }^{9}$ The three acceding countries were highly developed administratively, economically, and politically. Even so, their impending accession set off a row between existing member states over the threshold for a blocking minority in the reweighted system of QMV. The outcome was a political agreement - the Ioannina Compromise - whereby, following enlargement, the Council would strive to make legislative decisions on the basis of the pre-enlargement threshold for a blocking minority. Though it never had much of an effect and quickly faded into oblivion, the Ioannina Compromise was a timely reminder that institutional disputes, notably concerning the composition of a qualified majority, were likely to arise during future rounds of enlargement unless resolved beforehand as part of a comprehensive reform package.

Enlargement - not the imminent accession of the EFTA four (originally Norway also planned to join) but the possible accession, however distant, of the newly-inde-

9. F. GRANELL, The European Union's Enlargement Negotiations with Austria, Finland, Norway and Sweden, in: Journal of Common Market Studies, 1(1995), pp.117-142. 
pendent Central and Eastern European countries - had been the elephant in the room as the Maastricht IGC came to a close. While negotiating the Maastricht Treaty, however, most national leaders and the Commission President were eager to consolidate the existing EU rather than address the likely impact on EU policies and procedures of the end of the Cold War. Ironically, an unintended consequence of the Maastricht Treaty was to raise the bar for future members, by increasing the acquis communautaire and intensifying the administrative and regulatory burdens of membership. Thus, the Maastricht Treaty made EU accession more onerous for the newlyindependent countries of Central and Eastern Europe, which were struggling to develop effective post-Communist institutions and adequate administrative capacity.

Previous enlargements had the beneficial effect of prompting the EC to think about its fundamental nature. This was particularly true of the 1981 and 1986 enlargements, which had brought newly-democratic Greece, Portugal and Spain into the fold. ${ }^{10}$ Twenty years earlier, an application for an association agreement by Spain's then authoritarian government had triggered a discussion within the EC about the democratic principles underpinning European integration. ${ }^{11}$ The accession of Greece, Portugal and Spain cast the spotlight firmly on the EC's democratic foundations, as did the impending applications in the early 1990s of the Central and Eastern European countries. This coincided with growing concern among EU citizens over the quality of democracy at the European level of governance. Just as it would provide an opportunity to address institutional arrangements as well as the functioning of CFSP and JHA, the post-Maastricht IGC would allow the EU to elaborate further its democratic nature and tackle the democratic deficit.

Even before the follow-on IGC, the European Council took an important constitutional step in June 1993 when it developed the "Copenhagen Criteria" - the basic requirements for EU membership. Prospective members would be judged for accession based on the stability of their institutions guaranteeing democracy, rule of law, human rights, and protection of minorities; the existence of a functioning market economy; and the ability to take on the obligations of membership in a wide range of policy areas. ${ }^{12}$ Although largely a statement of the obvious, the timing of the European Council's declaration, and the inclusion in it of an explicit political criterion, reflected growing pressure within the EU to address Central and Eastern European enlargement in the immediate aftermath of the Maastricht Treaty.

Accordingly, whereas a review and possible restructuring of CFSP had been the original reason for convening the IGC that opened in March 1996, institutional reform in anticipation of Central and Eastern European enlargement instead became its main rationale. Indeed, the institutional implications of enlargement dominated the extensive preparations for the IGC. In the event, although another IGC may indeed have

10. A. COSTA PINTO, N.S. TEIXEIRA, Southern Europe and the Making of the European Union, 1945-1980s, Columbia University Press, New York, 2002.

11. D.C. THOMAS, Constitutionalization through Enlargement: The Contested Origins of the EU'S Democratic Identity, in: Journal of European Public Policy, 8(2006), pp.1190-1210.

12. Copenhagen European Council, Presidency Conclusions, Bulletin EC, 6(1993), point 1.4. 
been necessary at some point, arguably 1996-1997, less than five years after the Maastricht Treaty, was too soon to hold one. Moreover, a subsequent IGC was bound to pale by comparison with the negotiations that had resulted in the SEA and Maastricht, each of which was dominated by a compelling "big idea" (the single market and EMU). Institutional reform, improvement in the operation of CFSP and JHA, and the strengthening of the EU's democratic principles and processes were worthy, indeed necessary, changes. Yet they lacked the drama and popular appeal of more farreaching and consequential policy developments and, especially in the aftermath of the Maastricht ratification crisis, were unlikely to provide a big boost for European integration.

Perhaps the greatest challenge facing the 1996-1997 IGC, and subsequent IGCs, was that the debate about institutional reform had become so narrow and overwrought. In the negotiations leading to the SEA and the Maastricht Treaty, the issue of institutional change mostly concerned the legislative role of the EP and the scope of QMV. As already noted, the Ioannina Compromise of 1994 had introduced a new dimension to the discussion about QMV, thanks to enlargement. During the 1996-1997 IGC, most actors - national governments, the Commission, and the EP wanted to extend QMV to additional policy areas, but the issue now became wrapped up with the much more politically-sensitive question of the reweighting of Council votes. The reason for this was growing apprehension among the big member states over the decline in their relative voting power following successive rounds of enlargement, which had increased the number of small member states in the EU. Not unreasonably, the big member states wanted an increase in the number of their votes. Alternatively, they favoured the introduction of a double majority, combining the traditional requirement of a qualified majority with a new demographic criterion. Otherwise, they argued, a qualified majority could be formed following Central and Eastern European enlargement by a group of countries that together did not represent a majority of the EU's population - most of the Central and Eastern European candidate countries being future small member states.

By opening the latent division between big and small member states, negotiations about the future of QMV inevitably became linked to another controversial question: the size and composition of the Commission. As long ago as 1979, the Spierenburg Report on institutional reform had urged a diminution in the size of the Commission, which consisted of two Commissioners per big member state and one Commissioner per small member state. ${ }^{13}$ Jacques Delors, who became Commission President in 1985, complained that the Commission, which increased in size to seventeen Commissioners following Portuguese and Spanish accession to the EC in 1986, was too large and unwieldy, though it soon became the most successful Commission in EU history. ${ }^{14}$ By 1995 , when the EU acquired three new member states and the Com-

13. European Commission, Proposals for reform of the Commission of the European Communities and its services; report made at the request of the Commission by an Independent Review Body under the chairmanship of Mr. Dirk Spierenburg, Brussels, 24.09.1979.

14. K. ENDO, The Presidency of the European Commission under Jacques Delors: The Politics of Structured Leadership, St. Martin's, New York, 1999. 
mission increased to twenty members, the intellectual argument in favour of changing the basis for appointment to the Commission, thereby reducing its size, became compelling. The prospect of Central and Eastern European enlargement added to the urgency of the issue, though most small member states were loath to accept a solution that denied them representation in the Commission, despite the fact that Commissioners were supposed to be independent of the governments that nominated them. For their part, most big member states seemed willing to give up the right to appoint a second Commissioner only in return for additional votes in the Council or an overhaul of the system of QMV in ways that would increase their voting power.

Notwithstanding extensive preparatory work, negotiators failed to overhaul QMV and the Commission appointment system in the 1996-1997 IGC. ${ }^{15}$ EU leaders came close to a solution at the concluding summit, in Amsterdam in June 1997, but were unable to finalize a package deal. The reason may have been that Central and Eastern European enlargement, the catalyst for large-scale institutional reform, still seemed too distant to force EU leaders to act. Taking the easy way out, they decided to postpone institutional reform until another IGC, to take place at least one year before the EU enlarged to more than twenty member states.

Although it did not include institutional reform, the Amsterdam Treaty was by no means inconsequential for the EU. Aware of the special character of Central and Eastern European enlargement and sensitive to growing public concern about the EU's weak legitimacy, national leaders affirmed in the treaty that "the EU is founded on the principles of liberty, democracy, respect for human rights and fundamental freedoms, and the rule of law". Whereas the EU and the Communities that preceded it were political constructions, national governments had not explicitly imbued them with core political values. In the Amsterdam Treaty, by contrast, governments clearly stated what those values were and included a provision to sanction any member state that deviated from them. Drafted with the Central and Eastern European applicants in mind, this was one of the few provisions in the Amsterdam Treaty that owed its existence to impending enlargement.

The shadow of enlargement had nevertheless influenced the debate in the run-up to the Amsterdam Treaty on the possibility of institutionalizing differentiated integration. With the EU likely to include many more member states of varying sizes, interests, and capabilities, the idea of flexibly, whereby like-minded member states could integrate more quickly and closely than others, gained ground. Although some countries remained wary, a consensus emerged during the IGC that, in principle, flexibility should be included in the treaty so long as it was limited, in practice, to precisely defined conditions and would not endanger the acquis communautaire. The

15. On the 1996-1997 IGC and the Amsterdam Treaty, see G. FALKNER, M. NENTWICH, The Amsterdam Treaty: The Blueprint for the Future Institutional Balance?, in: K. NEUNREITHER, A. WIENER (eds), European Integration after Amsterdam: Institutional Dynamics and Prospects for Democracy, Oxford University Press, Oxford, 2000; F. LAURSEN (ed.), The Amsterdam Treaty: National Preference Formation, Interstate Bargaining and Outcome, Odense University Press, Odense, 2002. 
incorporation of both general "enabling" clauses for countries wishing to cooperate more closely and particular provisions governing the use of flexibility in certain policy areas was one of the most striking features of the Amsterdam Treaty. ${ }^{16}$

The treaty's innovations with regard to CFSP and JHA were significant, though not as far-reaching as proponents of deeper integration in these policy fields had hoped. The impetus for CFSP and JHA reform, despite developments in the Balkans and elsewhere, was not sufficient to overcome entrenched opposition among many national governments to sharing sovereignty in key aspects of foreign and security policy, and in police and judicial cooperation. The Maastricht Treaty had managed to bring CFSP and JHA formally and fully onto the EU agenda, but the follow-on review happened too soon to bring about extensive changes.

The Stability and Growth Pact, which national leaders adopted at the Amsterdam summit, before concluding the IGC, amounted to an important change in the EU's constitution. The pact originated in German doubts about the sustainability of EMU through budgetary discipline following the eventual launch of the euro. Accordingly, governments agreed that eurozone members whose budgets exceeded 3 percent of gross domestic product would be subject to financial penalties. While not part of the Amsterdam Treaty, the Stability and Growth Pact was tantamount to an informal treaty change, one that would have an enormous impact on EU developments and policies in the years ahead. ${ }^{17}$

Large-scale institutional reform was the obvious unfinished business of the Amsterdam Treaty. The EU finally tackled the so-called Amsterdam leftovers three years later in an IGC that resulted in the Nice Treaty. ${ }^{18}$ Central and Eastern European enlargement was still several years away, but seemed sufficiently imminent to ensure that EU leaders would agree on the necessary institutional reforms. The pre-Nice IGC also addressed institutional representation for the candidate countries, an issue that ordinarily would have been included in the accession negotiations and spelled-out in the ensuing accession treaties. The narrowness of the IGC agenda, which focused almost exclusively on voting weights and institutional representation, distinguished the new round of treaty reform from the SEA, Maastricht, and Amsterdam negotiations.

The pre-Nice IGC did indeed tackle the related issues of voting weights in the Council and national representation in the Commission, but in a highly unsatisfactory manner. Perhaps the very narrowness of the agenda precluded the kinds of linkages and side deals that facilitated success in previous IGCs, notably those resulting in the

16. A. STUBB, The Amsterdam Treaty and Flexible Integration, in: ECSA Review, 2(1998), pp.1-2.

17. P.M CROWLEY, The Stability and Growth Pact: Review, Alternatives and Legal Aspects, in: Current Politics and Economics of Europe, 3(2002), pp.225-244.

18. E. BEST, M. GRAY, A. STUBB (eds), Rethinking the European Union: IGC 2000 and Beyond, European Institute of Public Administration, Maastricht, 2002; M. GRAY, A. STUBB, The Treaty of Nice: Negotiating a Poisoned Chalice?, in: Journal of Common Market Studies, 39(2001), pp. 5-23; F. LAURSEN (ed.), The Treaty of Nice: Actor Preferences, Bargaining and Institutional Choice, Nijhoff/Brill, Leiden, 2006. 
SEA and the Maastricht Treaty. The big member states managed to get more votes in the Council, in return for a commitment to reduce the number of Commissioners to one only per member state until the EU expanded to twenty-seven members, at which time the EU would introduce a system, still to be worked out, to reduce the size of the Commission to fewer than the number of member states. In the meantime, big and small member states fought doggedly among each other, as well as between themselves, for as many Council votes as possible. Despite having a smaller population than Germany, France insisted for pragmatic and symbolic reasons on maintaining parity with its Eastern neighbour: each got the same number of additional votes. By contrast, the Netherlands secured more votes than Belgium, with which historically it was equal in the Council, much to the chagrin of its Benelux partner. Because the allocation of votes did not fairly reflect each country's population, the Nice agreement on QMV included a demographic criterion for the calculation of a qualified majority. Thus a legislative proposal would pass if it received a qualified majority (about 72 percent) of votes cast, representing an absolute majority of member states and, subject to a request by a national government, a qualified majority (62 percent) of the EU's population.

The Nice Treaty of 2001 had finally tackled the institutional implications of enlargement, but without introducing radical reform. The conduct of the IGC, during which national governments fought tenaciously over voting weights and Commission representation, tarnished the eventual agreement and brought the EU into disrepute. The final session of the negotiations, conducted by national leaders and the Commission President in Nice in December 2000, was especially inglorious. Without the cover of substantive policy issues, the IGC's almost exclusive focus on institutional affairs exposed the seeming pettiness of national positions and the glaring gap between rhetoric and reality in the conduct of EU affairs. Within ten years, treaty reform had deteriorated from the meatiness of Maastricht to the narrowness of Nice, bringing the credibility and utility of IGCs into question.

\section{The Constitutional Turn}

In 1999, eleven member states launched the third stage of EMU, irrevocably fixing their exchange rates and launching the single currency. Enlargement was the other big item on the EU's agenda. Yet the EU's response to impending enlargement had dominated two rounds of IGCs without producing radical institutional reform. Despite the magnitude of EMU and enlargement, the EU at the beginning of the new decade seemed stuck in acrimonious debates about arcane institutional issues that deepened public discontent with the broader European project. Aware of the need to lift the EU out of what had become a rut of treaty reform, EU leaders took a constitutional turn, intending to make a decisive break with the first ten years of the postMaastricht period of treaty change. 
The constitutional turn emerged from a post-Nice debate about the future of the EU that began even before the conclusion of the Nice Treaty. Key contributions included that of German Foreign Minister Joschka Fischer, who called in a speech in May 2000 for a Constitutional Treaty to establish a European Federation based on the principle of subsidiarity. ${ }^{19}$ Continuing the debate after the Nice Treaty was signed, Commission President Romano Prodi issued a White Paper on governance, following more than a year of consultations with politicians, officials and representatives of civil society. ${ }^{20}$

The debate culminated in the Laeken Declaration, issued by the European Council in December 2001. "Within the Union", the Declaration proclaimed,

"the European institutions must be brought closer to its citizens [who] undoubtedly support the Union's broad aims, but [...] want the European institutions to be less unwieldy and rigid and, above all, more efficient and open. [...] In short, citizens are calling for a clear, open, effective, democratically controlled Community approach".

The EU was in a dilemma: treaty reform required an IGC, which involved bargaining among national governments that tended to produce lowest-common-denominator or otherwise sub-optimal solutions. Accordingly, the European Council decided to pave the way for the next IGC "as broadly and openly as possible", by convening a convention

"composed of the main parties involved in the debate on the future of the Union [...]. to consider the key issues arising for the Union's future development and try to identify the various possible responses". ${ }^{21}$

The Laeken Declaration generated hope, if not confidence, that the EU was capable of breaking out of its narrow constitutional confines and embracing instead a broader, richer constitutional framework to address institutional constraints and citizen concerns.

Inevitably, perhaps, the Constitutional Convention, which opened in Brussels in February 2002, failed to live up to expectations. ${ }^{22}$ The Convention was intellectually interesting, with participants, representing national governments and national parliaments from the existing and candidate member states, as well as Commissioners and members of the EP, discussing a range of potential policy innovations and institutional reforms. Delegates drafted hundreds of proposals and treaty amendments. Yet national governments made most of the running, especially as the deadline of

19. Joschka Fischer, From Confederacy to Federation: Thoughts on the Finality of European Integration, speech at Humbolt University of Berlin, 12.05.2000.

20. $\operatorname{COM}(2001) 428$ final, European Commission, European Governance: A White Paper, 25.07.2001.

21. European Council (2001), Laeken Declaration on the Future of the European Union, http://europeanconvention.eu.int $/$ pdf $/ \mathrm{knen} . p d f$.

22. P. NORMAN, Accidental Constitution: The Making of Europe's Constitutional Treaty, $2^{\text {nd }}$ revised edition, Eurocomment, 2005; C. CLOSA, The Convention Method and the Transformation of EU Constitutional Politics, in: E. ODDVAR ERIKSEN, J.E. FOSSUM, A. JOSE MENDEZ, Developing a Constitution for Europe, Taylor and Francis, London, 2006, pp.184-207. 
June 2003 approached for the Convention to produce the Draft Constitutional Treaty. ${ }^{23}$

Contrary to the ethos of the Convention, the big-small country cleavage over institutional design soon resurfaced, with many of the small member states mounting a fierce rearguard action to maintain the right always to appoint a Commissioner. The big member states nevertheless managed to push through a provision for a college of only fifteen Commissioners. The debate over the modalities of QMV also followed familiar lines. Acutely aware of the limits of the Nice arrangement and their continuing loss of power as a result of enlargement, France and Germany pressed for a new voting system whereby half the number of member states representing at least 60 percent of the EU's population would constitute a qualified majority. Thanks in part to the support of Valéry Giscard d'Estaing, Chairman of the Convention, the two countries succeeded in having the new voting formula included in the Draft Constitutional Treaty.

The Constitutional Convention had taken place in part because of dissatisfaction with the traditional method of treaty reform, especially in the aftermath of the IGCs that preceded the Amsterdam and Nice treaties. Yet under the terms of the existing treaties, governments would have to hold an IGC in order to change the treaties. Whereas governments had worked behind the scenes to shape the outcome of the Constitutional Convention, they openly pushed for their preferences in the ensuing IGC. Once again, institutional issues predominated, with the small member states including those just about to join the EU - attempting to regain the right to representation in the Commission and two big countries - Poland and Spain - fighting to preserve the Nice arrangements for QMV, which were highly advantageous to them.

Under the circumstance, the post-Convention IGC immediately reverted to form. Threats by France and Germany to link the outcome to the upcoming budget negotiations (by implication cutting funds to Poland and Spain) and to forge ahead with a core group of member states (by implication excluding Poland and Spain) set a divisive tone for the negotiations. Changes of government in Poland and Spain, for reasons unrelated to the IGC, improved the chances for success. Hoping to signal a more accommodating approach to EU affairs, the two countries' new governments were willing to reach a compromise on a revised voting procedure. At the same time, the small member states eventually agreed to a Commission reduced in size, beginning in 2014. These reforms covered only a small part of the far-reaching Constitutional Treaty. Yet their negotiation dominated the IGC in a way that dramatically demonstrated the persistence and intensity of national rivalry over institutional arrangements in the EU.

It is questionable whether the Convention provided more legitimacy for the treaty reform process. ${ }^{24}$ Certainly, the Constitutional Treaty - the outcome of the Convention and the IGC - failed to generate public enthusiasm or support. Far from rallying

23. B. CRUM, Politics and Power in the European Convention, in: Politics, 1(2004), pp.1-11.

24. T. RISSE, M. KLEINE, Assessing the Legitimacy of the EU's Treaty Revision Methods, in: Journal of Common Market Studies, 1(2007), pp.69-80. 
public opinion to the EU, the Constitutional Treaty seemed to have generated additional cause for concern. The use of the word "constitutional" in the name of the treaty, and of titles such as "Foreign Minister" in the text, fuelled public unease with the state-like attributes of the emerging EU. Given the rise of Euroscepticism and, at best, widespread public indifference toward the EU, the fate of the Constitutional Treaty was highly uncertain. The decisions of the French President and the Dutch government to ratify the treaty by means of referendums gave a huge hostage to fortune. In both countries, most of the opposition had less to do with the treaty itself than with unrelated factors, such as fear of economic uncertainty (especially in France) and the government's unpopularity (especially in the Netherlands). It was hard to make a compelling case for the Constitutional Treaty, whose institutional innovations seemed arcane and lacked popular appeal. Not surprisingly, sizable majorities in both countries rejected the Treaty. ${ }^{25}$

The experience of previous treaty rejections suggested that governments would persist in pushing through the Constitutional Treaty. The difference this time was the impossibility of changing the treaty in ways that would be acceptable to all member states and would likely produce positive results in second referendums in France and the Netherlands, let alone in a referendum in the UK. Nevertheless governments were determined to salvage as much as possible of the Constitutional Treaty, having invested considerable time and political capital in it. Their best hope was to repackage the treaty in order to avoid holding new referendums, which they seemed bound to lose. For a start, they would need to call the Constitutional Treaty something else. The European Council agreed in June 2006 to adopt a "twin track" approach: first, using existing opportunities to deliver a "Europe of results"; second, exploring the possibility of rescuing the treaty with a minimum of change to it. ${ }^{26}$

The irony, once again, was the need to hold an IGC in order to revise the discredited Constitutional Treaty in ways that would make it more palatable politically. Patience with IGCs, even among national governments, had by then worn exceedingly thin. Germany, in the Council presidency in the first half of 2007, resolved to prepare a mandate for the IGC, which was scheduled to take place during the following Portuguese Presidency. In effect, Germany conducted the bulk of the negotiations during its presidency, bequeathing to the incoming Portuguese a revised treaty that governments could rubber-stamp in the IGC proper. Most of the changes made to the Constitutional Treaty were indeed cosmetic, which allowed governments to argue that the proposed "Reform Treaty" merely amended the existing treaties, not replace them with a new treaty, thereby obviating the need for referendums.

25. D. BEACH, The Constitutional Treaty: The Failed Formal Constitutionalization, in: F. LAURSEN, Designing the European Union ..., op.cit; pp.350-392; S. BARONCELLI, C. SPAGNOLO, L. SIMONA TALANI, Back to Maastricht: Obstacles to Constitutional Reform within the EU Treaty (1991-2007), Cambridge Scholars Publishing, Cambridge, 2008; F. LAURSEN (ed.), The Rise and Fall of the Constitutional Treaty, Nijhoff/Brill, Leiden, 2008.

26. European Council, Brussels European Council, June 15-16, Presidency Conclusions, 10633/1/06, REV 1, Brussels, 17.07.2006. 
Nevertheless the truncated IGC could not avoid reopening the contentious question of QMV. At issue this time was Poland's insistence on revisiting the double majority formula contained in the Constitutional Treaty. Understandably, Poland wanted to retain the Nice arrangement whereby its share of the total number of Council votes was almost equal to Germany's. The June 2007 summit, where EU leaders concluded the IGC, was suitably testy. Having resolved a variety of other issues, the European Council turned to the outstanding question of QMV. Under intense pressure from almost every other national delegation and the Commission President, the Polish delegation formally dropped its opposition to the double majority system in return for an arrangement to delay its entry into force until 2014. ${ }^{27}$

National leaders signed the new treaty at a ceremony in Lisbon in December 2007. Other than in Ireland, whose constitution mandates a referendum on EU treaty changes, there would not be any ratification referendums. Yet the result of the Irish referendum, held in June 2008, was 54 percent against. Once more, the fate of the Constitutional Treaty, this time in the form of its successor, the Lisbon Treaty, was in jeopardy. In contrast to the situation following the French and Dutch referendums, however, EU leaders could revert to their old tactic of offering the Irish government minor concessions with a view to holding a second referendum and appeasing a sufficient number of voters in order to secure a successful outcome. One Irish demand, however, was to prove highly significant. In the run-up to the referendum, the antitreaty side had exploited concern that Ireland's influence in Brussels would diminish following the reduction, in 2014, in the Commission's size. Never mind that this change was mandated long ago in the Nice Treaty. Given public sensitivity on the matter, the Irish government expressed confidence that it could hold and win a second referendum on the Lisbon Treaty if the European Council would agree to modify the Nice Treaty in order to retain one Commissioner per member state. ${ }^{28}$

What followed was a series of carefully choreographed steps. The European Council announced in December 2008 that it would decide in due course, as long as the Lisbon Treaty entered into force, to keep the Commission's size at one Commissioner from each member state. Six months later, the European Council agreed on a special protocol for Ireland, a largely meaningless form of words addressing some of Ireland's other concerns, to facilitate holding a second referendum and to help ensure a successful outcome. Soon afterwards, the Irish government announced that the referendum would take place in October 2009. Influenced less by the promised protocol than by the global financial crisis, which hit Ireland especially hard, Irish voters turned out in larger numbers and ratified the Lisbon Treaty in the second referendum. Once ratified by every other member state - the Czech Republic being the last holdout the Lisbon Treaty finally came into effect in December 2009.

27. European Policy Center, A Midsummer Night's Treaty, June 2007, http://www.epc.eu/ pub details.php?pub id $=416 \&$ cat $i d=5$.

28. J. O'BRENNAN, Ireland and the Lisbon Treaty: Quo Vadis?, CEPS Policy Brief No.176, October 2008. 
The import of the Lisbon Treaty went well beyond the institutional changes included in it, though institutional issues had dominated the preceding IGC. ${ }^{29}$ One of the key objectives of the Constitutional Treaty and subsequent Lisbon Treaty, as stated in the Laeken Declaration of 2001, was to simplify the EU's constitutional structure and decision-making procedures. One means of simplification was to do away with the Maastricht Treaty's three-pillar system, substituting for it a unitary EU. Whereas the Lisbon Treaty seemed to have achieved this objective, by retaining a separate, largely intergovernmental decision-making procedure for the CFSP, Lisbon replicated the SEA with respect to European Political Cooperation: it established a unitary treaty structure with an implicit intergovernmental pillar for foreign policy, security, and defence.

\section{Conclusion}

The Maastricht Treaty harks back to an apparently simpler time in the history of European integration. With only twelve member states, the EC was far more manageable than today's EU. Yet the possible accession of many newly-independent Central and Eastern European countries was already on the horizon. Maastricht represented the completion of an agenda that emerged in the late 1970s, in response to persistent economic setbacks and changing geo-political circumstances. It built on the evolution of European Political Cooperation, tentative steps in the area of justice and home affairs, and implementation of the single market program to deepen integration among existing member states before the EU would have to embark on an unprecedented round of enlargement. EMU, an ambitious objective with far-reaching political implications, seemed a fitting undertaking for an entity that enjoyed broad public support thanks to the presumed benefits of deeper market integration.

Though representing the end of a distinct phase in the history of European integration, Maastricht contained the seeds of future treaty reform, not least because of a clause calling for an IGC to review CFSP within five years. Yet the post-Maastricht agenda of institutional change, in light of impending Central and Eastern European enlargement, dominated the 1996-1997 and subsequent IGCs. An effort to alter the terms of the debate and legitimize the treaty reform process by convening the Constitutional Convention in 2003 failed to generate public support and wean the EU away from a preoccupation with seemingly narrow institutional interests. Rejection by French and Dutch voters of the Constitutional Treaty, then by Irish voters of the Lisbon Treaty, gave national governments a chance to focus the ensuing IGC squarely on institutional affairs. Whether preceded by a convention or consisting exclusively of an IGC, ambitious treaty reform had run out of public support and political steam

29. P. CRAIG, The Lisbon Treaty: Law, Politics, and Treaty Reform, revised edition, Oxford University Press, Oxford, 2013; J. ZILLER, The Treaty of Lisbon: Constitutional Treaty, Episode II, in: F. LAURSEN, Designing the European Union ..., op.cit. 
by the time that the Lisbon Treaty eventually came into effect. In its place, the EU faced a debate about results more than reform, with a corresponding shift of emphasis from input to output legitimacy.

Paradoxically, the main seeds of major treaty reform lay in Maastricht's major shortcoming: the weak foundations of EMU. The onset of the eurozone crisis exposed the fragility of monetary union without strong economic governance and effective political direction at the European level. Efforts to resolve the crisis have led to technical treaty changes in order to establish a permanent bailout fund and a fiscal pact primarily among eurozone members, though Britain's rejection of the latter resulted in the pact being concluded outside the EU treaty structure. The weakness of Maastricht's provisions for EMU was evident at the time of the original treaty negotiations, but wishful thinking masked its potential seriousness. Now that the extent of the problem is fully apparent, it may not be possible to seek the answer through wideranging treaty reform, thanks to public discontent and political dissatisfaction with the experience of treaty change - from Amsterdam to Lisbon - in the post-Maastricht period. 


\section{Politische Union ohne europäischen Demos?}

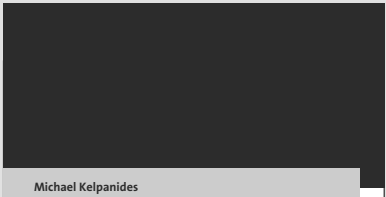

Politische Union ohne europäischen Demos?

Die fehlende Gemeinschaft der Europäer als Hindernis der politischen Integration

C Nomos

Die Gründung der europäischen Währungsunion hatte kontraproduktive Folgen: Sie hat nicht zur Konvergenz, sondern zu divergierenden ökonomischen Entwicklungen in den Euro-Ländern und zu übermäßiger Verschuldung der Südländer geführt, wodurch die größte Krise seit dem Zweiten Weltkrieg ausgelöst wurde.

Dieses Buch untersucht die tiefer liegenden ökonomischen, gesellschaftlichen, politischen und kulturellen Disparitäten zwischen den Mitgliedsgesellschaften, die der Entstehung einer solidarischen Gemeinschaft

\section{Politische Union ohne europäischen Demos?}

Die fehlende Gemeinschaft der Europäer als Hindernis der politischen Integration Von Michael Kelpanides 2013, ca. 460 S., brosch., ca. 69,- $€$ ISBN 978-3-8487-0309-8

Erscheint ca. Juli 2013

europäischer Bürger - eines europäischen Demos - massiv entgegenwirken. Die historisch erfolgreichen Fälle der Nationalstaatsbildung zeigen allerdings, dass starke Bürgerbewegungen für die Gründung der Nationalstaaten auf der Basis von kulturellen und gesellschaftlichen Affinitäten entstanden. Diese gibt es heute zwischen den Gesellschaften Nordwest- und Südosteuropas nicht. In dem Vergleich dieser stark miteinander kontrastierenden Ländergruppen wird Griechenland, das „schwächste Glied der Euro-Kette“ besonders berücksichtigt. 